\title{
PERHITUNGAN HARGA POKOK PENJUALAN MINYAK AKAR WANGI PADA PT. PULUS WANGI NUSANTARA DI KECAMATAN SAMARANG KABUPATEN GARUT
}

\section{Calculation Sales Price Of Vertiver Oil In PT Pulus Wangi Nusantara In Kecamatan Samarang, Kabupaten Garut}

\author{
Fitri Awaliyah ${ }^{*}$ \\ 1Program Studi Agribisnis Universitas Garut, Jl Raya Samarang No 52A Garut \\ fitriawaliyah@uniga.ac.id
}

\begin{abstract}
ABSTRAK
Usaha penyulingan minyak akar wangi tidak hanya menyangkut produksi penyulinganya tetapi juga menyangkut penjualannya. Perencanaan penjualan yang perlu diperhatikan adalah penetapan harga jual produk. Tujuan penelitian ini adalah mengetahui perhitungan harga jual dan keuntungan yang ditetapkan PT Pulus Wangi Nusantara menurut metode cost plus pricing (pendekatan full costing). Metode penelitian yang digunakan adalah studi kasus. Data yang digunakan adalah data produksi dan penjualan periode Januari 2011 sampai dengan Desember 2011, serta dianalisis dengan analisis penentuan harga jual menggunakan pendekatan full costing dan laporan rugi laba menurut pendekatan full costing. Hasil penelitian menunjukkan bahwa harga jual rata-rata yang ditetapkan PT Pulus Wangi sudah dapat menutup biaya yang dikeluarkan dan memberikan keuntungan.
\end{abstract}

Kata kata Kunci: minyak akar wangi, harga, cost plus pricing, full costing.

\begin{abstract}
The business of refining vetiver oil is not only concerned with the production of the refiner but also regarding the sale. Sales planning that needs to be considered is the determination of the selling price of the product. The purpose of this study was to determine the calculation of the selling price and profit set by PT Pulus Wangi Nusantara according to the cost plus pricing method (full costing approach). The research method used is a case study. The data used are production and sales data for the period January 2011 to December 2011, and analyzed with the analysis of selling price determination using the full costing approach and the income statement according to the full costing approach. The results showed that the average selling price set by PT Pulus Wangi was able to cover the costs incurred and provide a profit.
\end{abstract}

Keywords: vertiver oil, price, cost plus pricing, full costing. 


\section{PENDAHULUAN}

Indonesia merupakan salah satu negara pemasok minyak akar wangi yang cukup besar di samping Haiti, Cina dan Rumania. Damanik, 1995 dalam Jariyah dan Supangat (2007) mengemukakan bahwa sekitar 89 persen produk minyak akar wangi di Indonesia dihasilkan di Kabupaten Garut, selebihnya dari daerah Sukabumi, Bandung, Sumedang, Kuningan dan Wonosobo. Data perkembangan komoditas akar wangi di Kabupaten Garut bisa dilihat pada Tabel 1.

Tabel 1. Data perkembangan luas areal dan produksi komoditas akar wangi Tahun 2004-2008 di Kabupaten Garut

\begin{tabular}{crrr}
\hline \multirow{2}{*}{ Tahun } & \multicolumn{3}{c}{ Produksi } \\
\cline { 2 - 4 } & Luas Areal (ha) & Bahan Baku (ton) & $\begin{array}{c}\text { Minyak Akar } \\
\text { Wangi (ton) }\end{array}$ \\
\hline 2004 & 2.400 & 27.000 & 72 \\
2005 & 2.035 & 22.331 & 60 \\
2006 & 2.045 & 23.308 & 59 \\
2007 & 2.063 & 23.316 & 62 \\
2008 & 2.063 & 25.943 & 71 \\
\hline
\end{tabular}

Sumber: BPS Tahun 2004-2008

Indrawanto (2009) mengemukakan bahwa minyak akar wangi yang dihasilkan di Kabupaten Garut, hampir seluruhnya (lebih dari 90 persen) diekspor. Ekspor minyak akar wangi Indonesia rata-rata sekitar 60 ton per tahun atau sekitar 25 persen pasokan minyak akar wangi dunia (BPS, 2008). Permintaan dunia terhadap minyak akar wangi lebih dari 200ton/tahun, sehingga peluang pasar masih sangat terbuka.

Indonesia merupakan pemain penting dalam ekspor minyak akar wangi. Sentra produksi minyak akar wangi yang ada di Garut ini menghasilkan minyak akar wangi sebesar 34,5 ton pada tahun 2007 dan mempunyai areal tanaman akar wangi seluas 2.063 hektar (Departemen Pertanian, 2008). Indonesia telah mengekspor minyak akar wangi ke beberapa negara yaitu negara Perancis, Amerika Serikat, Jepang, India dan Singapura. Data perkembangan ekspor impor minyak akar wangi di Indonesia tahun 2001- 2005 bisa dilihat pada Tabel 2. 
Tabel 2. Perkembangan ekspor impor minyak akar wangi di Indonesia Tahun 20012005

\begin{tabular}{crrrr}
\hline \multirow{2}{*}{ Tahun } & \multicolumn{2}{c}{ Ekspor } & \multicolumn{2}{c}{ Impor } \\
\cline { 2 - 5 } & Volume (kg) & Nilai (US \$) & Volume (kg) & Nilai (US \$) \\
\hline 2001 & 1.583 .798 & 1.759 .241 & 2.312 & 43.728 \\
2002 & 79.714 & 1.973 .451 & 2.572 & 46.312 \\
2003 & 45.821 & 1.428 .682 & 2.465 & 18.680 \\
2004 & 58.444 & 2.445 .744 & 2.231 & 51.308 \\
2005 & 74.210 & 1.544 .618 & 532 & 22.890 \\
\hline
\end{tabular}

Sumber : BPS Tahun 2001-2005

Menurut data Kabupaten Garut Tahun 2010, pada tahun terakhir besar produk dan nilai produk minyak akar wangi yang diekspor adalah sebesar 23.520 kilogram atau senilai 1.516.208 US\$. Meskipun volume nilai ekspor mengalami kenaikan dari yang semula bernilai 1.175.920 US\$, namun kapasitas produk yang diekspor menurun dari tahun sebelumnya yang mencapai 29.100 kilogram. Produksi minyak akar wangi di Kabupaten Garut sesuai dengan kapasitas yang dimilikinya semuanya terserap pasar dengan harga jual yang memadai yaitu Rp 1.100.000,00 per kilogram. Harga ini meningkat dari tahun sebelumnya yang hanya dihargai $\operatorname{Rp} 800.000,00$ per kilogramnya. Meskipun demikian, sebenarnya harga tersebut masih dapat dioptimalkan lagi, jika kualitasnya ditingkatkan (Kabupaten Garut, 2011).

Terkait dengan harga jual, Mulyadi (2005) mengemukakan bahwa umumnya harga dan jasa standar ditentukan oleh perimbangan permintaan dan penawaran pasar. Penetapan harga jual juga akan tergantung pada pertimbangan mengenai biaya. Sugiri (1999) mengemukakan bahwa salah satu dasar yang digunakan untuk menentukan harga jual produk adalah harga pokok produk yang dihitung dengan pendekatan full costing. Menurut pendekatan ini harga pokok produk terdiri atas biaya bahan baku, biaya tenaga kerja langsung dan biaya overhead pabrik tetap dan variabel. Harga jual yang ditargetkan adalah harga pokok produk ditambah dengan mark up. PT Pulus Wangi Nusantara menetapkan harga jual minyak akar wangi masih menggunakan cara yang sederhana dan belum menggunakan pembukuan keuangan yang rapi sehingga nilai keuangan yang diperoleh masih tidak terstrukstur. Selain itu pula harga jual produk yang telah ditetapkan perusahaan diharapkan dapat mendatangkan keuntungan bagi perusahaan dan tidak menderita kerugian akibat fluktuasi harga dalam situasi penawaran dan permintaan pasar yang tidak tentu.

Melihat kendala yang dapat menghambat perusahaan dalam usahanya, perlu dilakukan suatu evaluasi mengenai perhitungan harga pokok penjualan minyak akar wangi. Tujuan evaluasi perhitungan harga pokok penjualan tersebut adalah untuk mengetahui seberapa besar laba yang diperoleh 
perusahaan dengan menggunakan harga jual yang telah ditentukan perusahaan tersebut, sehingga laba yang diperoleh mampu menutup semua biaya yang dikeluarkan dalam memproduksi minyak akar wangi. Metode perhitungan harga jual yang ditetapkan perusahaan dan perolehan laba akan dihitung menurut metode cost plus pricing (pendekatan full costing).

\section{METODOLOGI}

\section{Lokasi dan Waktu Penelitian}

Penelitian dilaksanakan pada perusahaan penyulingan minyak akar wangi “PT. Pulus Wangi Nusantara” di Desa Sukakarya, Kecamatan Samarang, Kabupaten Garut. Penelitian ini dilaksanakan dari Tanggal 3 Februari sampai 20 Februari 2012.

\section{Metode Analisis}

Metode yang digunakan pada penelitian ini adalah studi kasus. Metode pengumpulan data dalam penelitian ini menggunakan metode wawancara dan observasi. Jenis data yang digunakan adalah data primer dan sekunder. Metode analisis yang digunakan dalam penelitian ini adalah perhitungan harga jual dan keuntungan berdasarkan metode cost plus pricing (pendekatan full costing). Penentuan kedua harga jual menggunakan metode analisis sebagai berikut:

1. Perhitungan biaya produksi. Menurut Mulyadi (2005) cara menentukan biaya produksi adalah sebagai berikut:

\begin{tabular}{|ll|}
\hline Biaya bahan baku & $x x x x x$ \\
Biaya tenaga kerja langsung & $x \times x x x$ \\
Biaya overhead pabrik tetap dan variabel & $x x x x x$ \\
\cline { 2 - 2 } & \\
Jumlah biaya produksi & $x x x x x$ \\
\hline
\end{tabular}

2. Mengetahui apakah usaha yang dilakukan oleh perusahaan sudah memberikan keuntungan bagi perusahaan, digunakan laporan rugi laba menurut pendekatan full costing. Beberapa perhitungan dalam laporan rugi laba menurut pendekatan full costing yaitu:

a. Menentukan harga pokok penjualan:

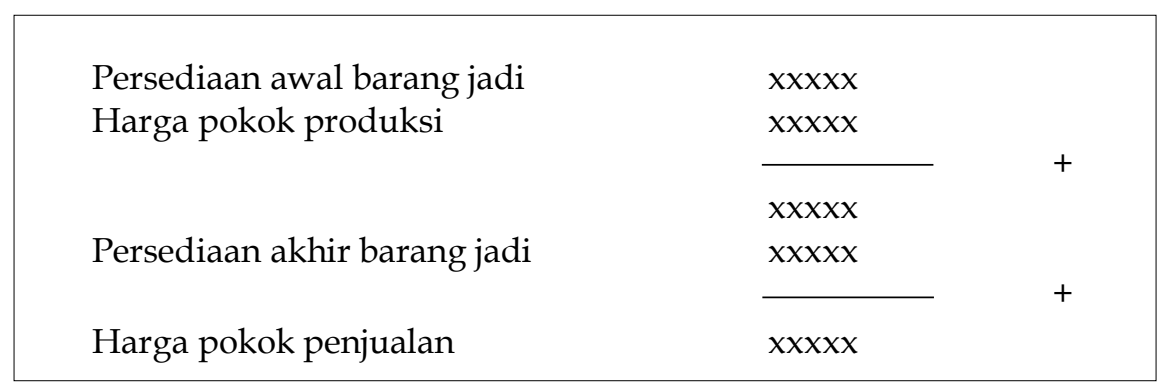


b. Menentukan laba bruto:

$$
\text { Laba bruto }=\text { hasil penjualan }- \text { harga pokok penjualan }
$$

c. Menentukan laba bersih:

\begin{tabular}{|c|c|}
\hline Laba bruto & $X X X X X$ \\
\hline Biaya komersial (administrasi dan pemasaran) & $x x x x x$ \\
\hline Laba sebelum pajak & $x \times x x x$ \\
\hline Pajak & $x \times x x x$ \\
\hline Laba bersih & $\operatorname{xxxxx}$ \\
\hline
\end{tabular}

Format laporan rugi laba berdasarkan pendekatan full costing, adalah sebagai berikut:

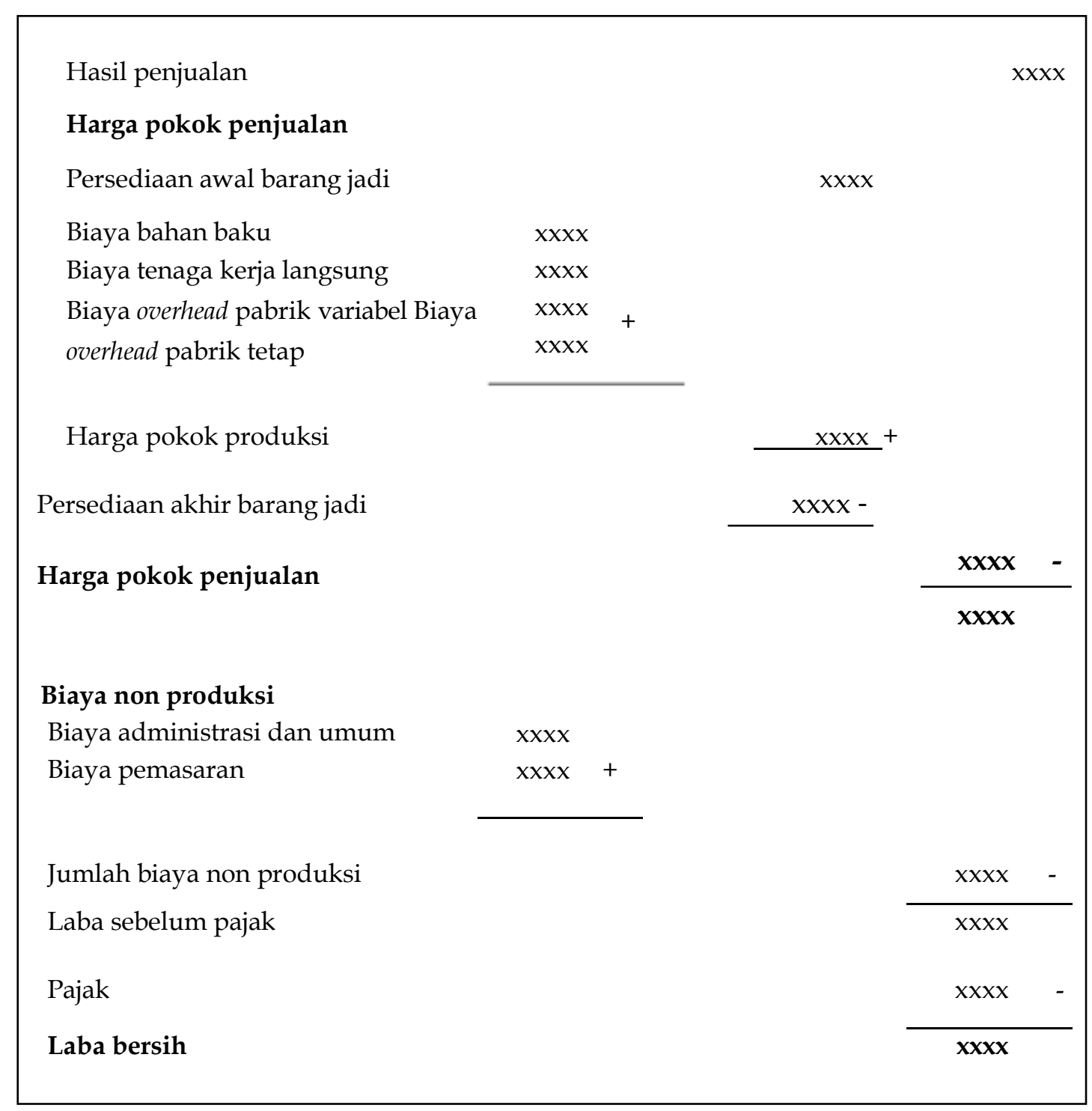




\section{HASIL DAN PEMBAHASAN}

Mulyadi (2005) menyatakan bahwa dalam pembuatan produk terdapat dua kelompok biaya, yaitu biaya produksi dan biaya non produksi. Biaya produksi merupakan biaya yang dikeluarkan dalam pengolahan bahan baku menjadi produk, sedangkan biaya non produksi merupakan biaya-biaya yang dikeluarkan untuk kegiatan-kegiatan non produksi misalnya kegiatan pemasaran dan kegiatan administrasi.

\section{Biaya produksi}

Biaya produksi ini terdiri atas biaya bahan baku, biaya tenaga kerja langsung dan biaya overhead pabrik. Rincian biaya produksi pada PT Pulus Wangi Nusantara adalah sebagai berikut:

\section{a. Biaya bahan baku}

Biaya bahan baku yaitu biaya untuk pengadaan akar wangi. Akar wangi yang dibutuhkan pabrik setiap ketelnya rata-rata adalah dua ton dengan harga yang berkisar Rp3.000,00 - Rp4.000,00 tiap kilogramnya. Fluktuasi harga pada bahan baku akar wangi ini kerap terjadi setiap bulannya karena faktor cuaca serta kurang tepatnya masa tanam dan panen. yang dilakukan petani.

Tabel 3. Biaya bahan baku minyak akar wangi per bulan pada PT Pulus Wangi Nusantara Tahun 2011

\begin{tabular}{lrrr}
\hline \multicolumn{1}{c}{ Bulan } & $\begin{array}{c}\text { Jumlah Akar } \\
\text { Wangi (kg) }\end{array}$ & $\begin{array}{c}\text { Harga Akar Wangi } \\
\text { per kg (Rp) }\end{array}$ & $\begin{array}{c}\text { Jumlah Biaya } \\
\text { Bahan Baku (Rp) }\end{array}$ \\
\hline Januari & 51.000 & 3.000 & 153.000 .000 \\
Februari & 61.000 & 3.500 & 213.500 .000 \\
Maret & 59.000 & 3.700 & 218.300 .000 \\
April & 48.000 & 3.500 & 168.000 .000 \\
Mei & 54.000 & 3.700 & 199.800 .000 \\
Juni & 52.000 & 3.500 & 182.000 .000 \\
Juli & 46.000 & 3.300 & 151.800 .000 \\
Agustus & 47.000 & 3.400 & 159.800 .000 \\
September & 63.000 & 3.500 & 220.500 .000 \\
Oktober & 73.000 & 3.500 & 255.500 .000 \\
Nopember & 45.000 & 3.300 & 148.500 .000 \\
Desember & 43.000 & 3.300 & 141.900 .000 \\
\hline Jumlah Total & $\mathbf{6 4 2 . 0 0 0}$ & & $\mathbf{2 . 2 1 2 . 6 0 0 . 0 0 0}$ \\
\hline Rata-Rata & $\mathbf{5 3 . 5 0 0}$ & & $\mathbf{1 8 4 . 3 8 3 . 3 3 3}$ \\
\hline
\end{tabular}

Sumber: data primer, 2012.

Pabrik tiap harinya setidaknya harus mendatangkan bahan baku sekitar 2 ton untuk mencukupi kebutuhan proses produksi pada tiap ketel. Setiap dua ton akar wangi dapat menghasilkan minyak akar wangi seberat $6-8 \mathrm{~kg}$. Besarnya biaya bahan baku pembuatan minyak akar wangi pada PT Pulus Wangi 
Nusantara dapat dilihat pada Tabel 3.

Tabel 3 menunjukkan bahwa biaya bahan baku total terbesar pada bulan Oktober yaitu seberat 73.000 kilogram akar wangi seharga Rp255.500.000,00 hal ini terjadi pada bulan Oktober ini kuantitas akar wangi yang digunakan dalam proses produksi berada pada jumlah tertinggi dan harga akar wangi tiap kilogramnya mengalami kenaikan sampai Rp3.500,00. Fluktuasi harga bahan baku sangat mempengaruhi biaya produksi di mana perusahaan harus mengeluarkan biaya produksi yang lebih tinggi ketika harga akar wangi naik namun tidak disertai dengan jaminan kualitas akar wangi yang baik dan kuantitas yang sesuai dengan yang dibutuhkan perusahaan. Hal itu terjadi karena petani memanen akar wangi terlalu muda, akar wangi dipanen ketika musim hujan, dan adanya persaingan antar pengusaha minyak akar wangi untuk mendapatkan bahan baku, yang tidak jarang menyebabkan harga bahan baku naik namun akar wangi yang diproses mempunyai rendemen sedikit.

\section{b. Biaya tenaga kerja langsung}

Tenaga kerja langsung adalah tenaga kerja yang berperan langsung dalam proses pembuatan minyak akar wangi. Proses produksi minyak akar wangi yang memerlukan tenaga kerja langsung terdiri atas proses penjemuran dan perajangan, penyulingan serta pemisahan. Tenaga kerja langsung berjumlah 3 orang, dengan pembagian kerja 1 orang untuk penjemuran dan perajangan, 1 orang menyuling dan 1 orang menyaring minyak yang masih bercampur dengan air. Jam kerja para pekerja tidak terjadwal tetap, melainkan menyesuaikan dengan proses penyulingan, yang lama prosesnya berkisar $10-13$ jam.

Upah yang diberlakukan adalah sistem upah sesuai produksi per ketel. Adapun upah produksi untuk setiap ketel baik itu yang bekerja untuk menjemur, menyuling dan menyaring masing-masing diberi upah Rp50.000,00 yang diberikan secara akumulatif yaitu setiap hari Kamis karena perusahaan tidak libur pada hari Minggu, tetapi liburnya pada hari Jum'at. Besarnya biaya tenaga kerja langsung pada PT Pulus Wangi Nusantara tersaji pada Tabel 4. 
Tabel 4. Biaya tenaga kerja langsung per bulan pada PT Pulus Wangi Nusantara Tahun 2011

\begin{tabular}{lrrr}
\hline \multicolumn{1}{c}{ Bulan } & $\begin{array}{c}\text { Produksi } \\
\text { (Ketel) }\end{array}$ & $\begin{array}{c}\text { Biaya TK Langsung } \\
\text { per Ketel (Rp) }\end{array}$ & $\begin{array}{c}\text { Jumlah Biaya TK } \\
\text { Langsung (Rp) }\end{array}$ \\
\hline Januari & 26 & 150.000 & 3.900 .000 \\
Februari & 30 & 150.000 & 4.500 .000 \\
Maret & 29 & 150.000 & 4.350 .000 \\
April & 24 & 150.000 & 3.600 .000 \\
Mei & 27 & 150.000 & 4.050 .000 \\
Juni & 26 & 150.000 & 3.900 .000 \\
Juli & 23 & 150.000 & 3.450 .000 \\
Agustus & 24 & 150.000 & 3.600 .000 \\
September & 31 & 150.000 & 4.650 .000 \\
Oktober & 36 & 150.000 & 5.400 .000 \\
November & 22 & 150.000 & 3.300 .000 \\
Desember & 21 & 150.000 & 3.150 .000 \\
\hline Jumlah Total & $\mathbf{3 1 9}$ & $\mathbf{1 . 8 0 0 . 0 0 0}$ & $\mathbf{4 7 . 8 5 0 . 0 0 0}$ \\
\hline Rata-rata & $\mathbf{2 7}$ & $\mathbf{1 5 0 . 0 0 0}$ & $\mathbf{3 . 9 8 7 . 5 0 0}$ \\
\hline
\end{tabular}

Sumber: data primer diolah, 2012

Tabel 4 menunjukkan bahwa biaya tenaga kerja tertinggi terjadi pada bulan Oktober yaitu sebesar Rp5.400.000,00 hal ini terjadi karena adanya peningkatan produksi minyak akar wangi hingga 36 ketel sehingga meningkat pula biaya tenaga kerja langsung perusahaan.

\section{c. Biaya overhead pabrik}

Biaya overhead pabrik yaitu biaya yang dikeluarkan untuk produksi minyak akar wangi, selain biaya bahan baku dan biaya tenaga kerja langsung. Biaya overhead pabrik terdiri atas:

1) Biaya overhead pabrik variabel.

Biaya overhead pabrik variabel adalah biaya overhead pabrik yang jumlahnya dipengaruhi oleh volume minyak akar wangi yang di produksi, biaya overhead pabrik variabel meliputi biaya bahan bakar dan biaya tenaga kerja pengangkut. Bahan bakar untuk penyulingan berupa oli bekas, setiap ketel produksi membutuhkan 300 liter oli bekas. Sedangkan tenaga kerja pengangkut berjumlah 23 orang yang bersifat borongan. Upah yang diberikan kepada tenaga kerja pengangkut adalah Rp100,00 tiap kilogram akar wangi yang diangkut. Informasi biaya overhead pabrik variabel dapat dilihat pada Tabel 5. 
Tabel 5. Biaya overhead pabrik variabel per bulan pada PT Pulus Wangi Nusantara Tahun 2011.

\begin{tabular}{|c|c|c|c|c|c|c|c|}
\hline \multirow[b]{2}{*}{ Bulan } & \multicolumn{3}{|c|}{ Biaya Bahan Bakar } & \multicolumn{3}{|c|}{ Biaya TK Pengangkut } & \multirow[b]{2}{*}{$\begin{array}{c}\text { Jumlah } \\
\text { Biaya } \\
\text { Overhead } \\
\text { Pabrik } \\
\text { Variabel } \\
\text { (Rp) }\end{array}$} \\
\hline & $\begin{array}{c}\text { Kebutuhan } \\
\text { Bahan } \\
\text { Bakar } \\
\text { (liter) }\end{array}$ & $\begin{array}{c}\text { Harga } \\
\text { Bahan } \\
\text { Bakar per } \\
\text { Liter (Rp) }\end{array}$ & $\begin{array}{c}\text { Jumlah } \\
\text { Biaya } \\
\text { Bahan } \\
\text { Bakar (Rp) }\end{array}$ & $\begin{array}{c}\text { Bahan } \\
\text { Baku } \\
\text { yang } \\
\text { Diangkut } \\
\text { (kg) }\end{array}$ & $\begin{array}{l}\text { Upah per } \\
\text { kg (Rp) }\end{array}$ & $\begin{array}{c}\text { Jumlah } \\
\text { Biaya TK } \\
\text { (Rp) }\end{array}$ & \\
\hline Januari & 7.800 & 2.500 & 19.500 .000 & 25.500 & 100 & 2.550 .000 & 22.050 .000 \\
\hline Februari & 9.000 & 2.500 & 22.500 .000 & 30.500 & 100 & 3.050 .000 & 25.550 .000 \\
\hline Maret & 8.700 & 2.600 & 22.620 .000 & 29.500 & 100 & 2.950 .000 & 25.570 .000 \\
\hline April & 7.200 & 2.600 & 18.720 .000 & 24.000 & 100 & 2.400 .000 & 21.120 .000 \\
\hline Mei & 8.100 & 2.700 & 21.870 .000 & 27.000 & 100 & 2.700 .000 & 24.570 .000 \\
\hline Juni & 7.800 & 2.800 & 21.840 .000 & 26.000 & 100 & 2.600 .000 & 24.440 .000 \\
\hline Juli & 6.900 & 2.800 & 19.320 .000 & 23.000 & 100 & 2.300 .000 & 21.620 .000 \\
\hline Agustus & 7.200 & 2.900 & 20.880 .000 & 23.500 & 100 & 2.350 .000 & 23.230 .000 \\
\hline September & 9.300 & 3.000 & 27.900 .000 & 31.500 & 100 & 3.150 .000 & 31.050 .000 \\
\hline Oktober & 10.800 & 3.000 & 32.400 .000 & 36.500 & 100 & 3.650 .000 & 36.050 .000 \\
\hline Nopember & 6.600 & 3.000 & 19.800 .000 & 22.500 & 100 & 2.250 .000 & 22.050 .000 \\
\hline Desember & 6.300 & 3.000 & 18.900 .000 & 21.500 & 100 & 2.150 .000 & 21.050 .000 \\
\hline $\begin{array}{l}\text { Jumlah } \\
\text { Total }\end{array}$ & 95.700 & & 266.250 .000 & 321.000 & & 32.100 .000 & 298.350 .000 \\
\hline Rata-rata & 7.975 & 2.783 & 22.187 .500 & 26.750 & 100 & 2.675 .000 & 24.862 .500 \\
\hline
\end{tabular}

Sumber: data primer diolah, 2012

Tabel 5 menununjukkan bahwa biaya overhead variabel tertinggi terjadi pada bulan Oktober yaitu sebesar Rp36.050.000,00 hal ini terjadi karena jumlah akar wangi yang diproses tertinggi sehingga biaya overhead pabrik variabel ikut mengalami peningkatan pula, sedangkan biaya overhead pabrik variabel terendah terjadi pada bulan Desember yaitu sebesar Rp21.050.000,00. Hal ini terjadi karena jumlah akar wangi yang diproses terendah sehingga biaya overhead pabrik mengalami penurunan.

\section{2) Biaya overhead pabrik tetap}

Biaya overhead pabrik tetap merupakan biaya overhead pabrik yang jumlahnya tidak dipengaruhi oleh volume minyak akar wangi yang diproduksi. Biaya overhead pabrik tetap ini terdiri atas biaya pemeliharaan pabrik, biaya perawatan mesin, biaya penyusutan gedung, biaya pajak bumi dan bangunan, biaya pajak retribusi dan biaya sewa kendaraan. PT Pulus Wangi Nusantara dalam memproduksi minyak akar wangi tiap bulannya mengeluarkan biaya overhead pabrik tetap sebesar Rp1.404.994,00. Biaya tersebut dikeluarkan perusahaan untuk menunjang produksi minyak akar wangi dalam tiap produksi sehari- harinya. Informasi biaya overhead pabrik tetap bisa dilihat pada Tabel 6 . 
Tabel 6. Biaya overhead pabrik tetap per bulan pada PT Pulus Wangi Nusantara Tahun 2011

\begin{tabular}{|c|c|c|c|c|c|c|c|c|}
\hline Bulan & $\begin{array}{c}\text { Biaya } \\
\text { Pemelihara } \\
\text { an Pabrik } \\
\text { (Rp) }\end{array}$ & $\begin{array}{c}\text { Biaya } \\
\text { Perawatan } \\
\text { Mesin } \\
(\mathrm{Rp})\end{array}$ & $\begin{array}{c}\text { Biaya } \\
\text { Penyusutan } \\
\text { (Rp) }\end{array}$ & $\begin{array}{c}\text { Biaya } \\
\text { Pembelian } \\
\text { Alat } \\
\text { Pabrik } \\
\text { (Rp) }\end{array}$ & $\begin{array}{l}\text { Biaya } \\
\text { PBB } \\
\text { (Rp) }\end{array}$ & $\begin{array}{c}\text { Biaya } \\
\text { Retribusi } \\
\quad(\mathrm{Rp})\end{array}$ & $\begin{array}{c}\text { Biaya } \\
\text { Sewa } \\
\text { Kendaraan } \\
(R p)\end{array}$ & $\begin{array}{c}\text { Jumlah } \\
\text { BOP } \\
\text { Tetap } \\
\text { (Rp) }\end{array}$ \\
\hline Januari & 45.000 & 60.000 & 939.994 & 183.333 & 16.667 & 25.000 & 135.000 & 1.404 .994 \\
\hline Februari & 45.000 & 60.000 & 939.994 & 183.333 & 16.667 & 25.000 & 135.000 & 1.404 .994 \\
\hline Maret & 45.000 & 60.000 & 939.994 & 183.333 & 16.667 & 25.000 & 135.000 & 1.404 .994 \\
\hline April & 45.000 & 60.000 & 939.994 & 183.333 & 16.667 & 25.000 & 135.000 & 1.404 .994 \\
\hline Mei & 45.000 & 60.000 & 939.994 & 183.333 & 16.667 & 25.000 & 135.000 & 1.404 .994 \\
\hline Juni & 45.000 & 60.000 & 939.994 & 183.333 & 16.667 & 25.000 & 135.000 & 1.404 .994 \\
\hline Juli & 45.000 & 60.000 & 939.994 & 183.333 & 16.667 & 25.000 & 135.000 & 1.404 .994 \\
\hline Agustus & 45.000 & 60.000 & 939.994 & 183.333 & 16.667 & 25.000 & 135.000 & 1.404 .994 \\
\hline September & 45.000 & 60.000 & 939.994 & 183.333 & 16.667 & 25.000 & 135.000 & 1.404 .994 \\
\hline Oktober & 45.000 & 60.000 & 939.994 & 183.333 & 16.667 & 25.000 & 135.000 & 1.404 .994 \\
\hline Nopember & 45.000 & 60.000 & 939.994 & 183.333 & 16.667 & 25.000 & 135.000 & 1.404 .994 \\
\hline Desember & 45.000 & 60.000 & 939.994 & 183.333 & 16.667 & 25.000 & 135.000 & 1.404 .994 \\
\hline $\begin{array}{l}\text { Jumlah } \\
\text { Total }\end{array}$ & 540.000 & 720.000 & 11.279 .933 & 2.200 .000 & 200.000 & 300.000 & 1.620 .000 & 16.859 .933 \\
\hline Rata-rata & 45.000 & 60.000 & 939.994 & 183.333 & 16.667 & 25.000 & 135.000 & 1.404 .994 \\
\hline
\end{tabular}

Sumber: data primer, diolah 2012.

\section{d. Biaya produksi tiap kilogram minyak akar wangi}

Biaya produksi untuk tiap kilogram minyak akar wangi dihitung dengan cara menjumlahkan semua biaya yang telah dikeluarkan oleh perusahaan, yang terdiri atas biaya bahan baku, biaya tenaga kerja langsung dan biaya overhead pabrik kemudian dibagi volume minyak akar wangi yang yang dihasilkan pada tiap bulannya. Besarnya biaya produksi dapat dilihat pada Tabel 7.

Tabel 7. Biaya produksi minyak akar wangi tiap kilogram per bulan pada PT Pulus Wangi Nusantara Tahun 2011

\begin{tabular}{lccrrr}
\hline \multicolumn{1}{c}{ Bulan } & $\begin{array}{c}\text { Jumlah Biaya } \\
\text { Bahan Baku } \\
\mathbf{( R p )}\end{array}$ & $\begin{array}{c}\text { Jumlah Biaya } \\
\text { TKL } \mathbf{( R \mathbf { p } )}\end{array}$ & $\begin{array}{c}\text { Jumlah BOP } \\
\text { Total (Rp) }\end{array}$ & $\begin{array}{c}\text { Jumlah Hasil } \\
\text { Produksi } \\
\mathbf{( K g )}\end{array}$ & $\begin{array}{r}\text { Jumlah Biaya } \\
\text { Produksi/Kg } \\
\mathbf{( R p )}\end{array}$ \\
\hline Januari & 153.000 .000 & 3.900 .000 & 23.454 .994 & 153 & $1.178 .790,8$ \\
Februari & 213.500 .000 & 4.500 .000 & 26.954 .994 & 247 & $991.720,6$ \\
Maret & 218.300 .000 & 4.350 .000 & 26.974 .994 & 238 & $1.048 .844,5$ \\
April & 168.000 .000 & 3.600 .000 & 22.524 .994 & 146 & $1.329 .623,2$ \\
Mei & 199.800 .000 & 4.050 .000 & 25.974 .994 & 218 & $1.054 .243,0$ \\
Juni & 182.000 .000 & 3.900 .000 & 25.844 .994 & 210 & $1.008 .309,4$ \\
Juli & 151.800 .000 & 3.450 .000 & 23.024 .994 & 185 & $963.648,6$ \\
Agustus & 159.800 .000 & 3.600 .000 & 24.634 .994 & 190 & $989.657,8$ \\
September & 220.500 .000 & 4.650 .000 & 32.454 .994 & 254 & $1.014 .192,8$ \\
Oktober & 255.500 .000 & 5.400 .000 & 37.454 .994 & 295 & $1.011 .372,8$ \\
Nopember & 148.500 .000 & 3.300 .000 & 23.454 .994 & 180 & $973.638,8$ \\
Desember & 141.900 .000 & 3.150 .000 & 22.454 .994 & 130 & $1.288 .499,9$ \\
\hline Jumlah Total & $\mathbf{2 . 2 1 2 . 6 0 0 . 0 0 0}$ & $\mathbf{4 7 . 8 5 0 . 0 0 0}$ & $\mathbf{3 1 5 . 2 0 9 . 9 3 3}$ & $\mathbf{2 . 4 4 6}$ & $\mathbf{1 2 . 8 5 2 . 5 4 3}$ \\
\hline Rata-rata & $\mathbf{1 8 4 . 3 8 3 . 3 3 3}$ & $\mathbf{3 . 9 8 7 . 5 0 0}$ & $\mathbf{2 6 . 2 6 7 . 4 9 4}$ & $\mathbf{2 0 4}$ & $\mathbf{1 . 0 7 1 . 0 4 5}$ \\
\hline
\end{tabular}

Sumber : data primer diolah, 2012 
Tabel 7 menunjukkan bahwa jumlah biaya produksi minyak akar wangi tiap kilogram tertinggi dikeluarkan perusaahaan pada bulan April sebesar Rp1.329.623,2. Hal ini terjadi karena adanya ketidakefisiensian dalam proses produksi dimana pada bulan April ini hasil rendemen minyak menurun. Faktor utama yang paling mempengaruhi tingkat efisiensi produksi minyak akar wangi adalah kualitas akar wangi itu sendiri, jika kualitasnya baik, maka akan menghasilkan rendemen yang tinggi, namun jika kualitasnya buruk maka rendemen yang dihasilkanpun sedikit. Kualitas baik atau buruknya akar wangi dipengaruhi oleh cuaca ketika memanen dan umur akar wangi itu sendiri ketika dipanen dan diproduksi untuk penyulingan.

\section{Biaya non produksi}

Biaya non produksi merupakan biaya yang dikeluarkan perusahaan untuk membiayai selain kegiatan produksi. Biaya non produksi pada PT Pulus Wangi Nusantara terdiri atas biaya pemasaran dan biaya administrasi dan umum. Besarnya biaya non produksi pada PT Pulus Wangi Nusantara dapat dilihat pada Tabel 8 .

Tabel 8. Biaya non produksi minyak akar wangi per bulan pada PT Pulus Wangi Nusantara Tahun 2011

\begin{tabular}{lrrr}
\hline \multicolumn{1}{c}{ Bulan } & $\begin{array}{c}\text { Jumlah Biaya } \\
\text { Pemasaran (Rp) }\end{array}$ & $\begin{array}{c}\text { Jumlah Biaya } \\
\text { Administrasi (Rp) }\end{array}$ & $\begin{array}{c}\text { Jumlah Biaya Non } \\
\text { Produksi (Rp) }\end{array}$ \\
\hline Januari & 1.373 .000 & 2.873 .000 & 4.246 .000 \\
Februari & 1.562 .000 & 2.786 .000 & 4.348 .000 \\
Maret & 1.537 .000 & 2.910 .000 & 4.447 .000 \\
April & 1.325 .000 & 2.892 .000 & 4.217 .000 \\
Mei & 1.515 .000 & 2.937 .000 & 4.452 .000 \\
Juni & 1.507 .000 & 2.797 .000 & 4.304 .000 \\
Juli & 1.423 .000 & 2.960 .000 & 4.383 .000 \\
Agustus & 1.405 .000 & 2.852 .000 & 4.257 .000 \\
September & 1.526 .000 & 2.945 .000 & 4.471 .000 \\
Oktober & 1.578 .000 & 2.857 .000 & 4.435 .000 \\
Nopember & 1.380 .000 & 2.927 .000 & 4.307 .000 \\
Desember & 1.342 .000 & 2.915 .000 & 4.257 .000 \\
\hline Jumlah Total & $\mathbf{1 7 . 4 7 3 . 0 0 0}$ & $\mathbf{3 4 . 6 5 1 . 0 0 0}$ & $\mathbf{5 2 . 1 2 4 . 0 0 0}$ \\
\hline Rata-rata & $\mathbf{1 . 4 5 6 . 0 8 3}$ & $\mathbf{2 . 8 8 7 . 5 8 3}$ & $\mathbf{4 . 3 4 3 . 6 6 7}$ \\
\hline
\end{tabular}

Sumber: data primer diolah, 2012

Data dari Tabel 8 menunjukkan bahwa jumlah biaya non produksi tertinggi terjadi pada bulan September yaitu sebesar Rp4.471.000,00. Hal ini terjadi karena adanya peningkatan pada biaya distribusi pemasaran minyak akar wangi serta adanya peningkatan pula pada biaya air, listrik, dan telepon yang digunakan oleh perusahaan, namun biaya non produksi terendah terjadi pada bulan April sebesar Rp4.217.000,00. Hal ini terjadi karena adanya penurunan 
pada biaya distribusi pemasaran minyak akar wangi serta adanya penurunan pula pada biaya air, listrik, dan telepon yang digunakan oleh perusahaan.

\section{Harga jual}

Harga jual adalah jumlah uang yang dibebankan oleh PT Pulus Wangi Nusantara kepada pembeli atas minyak akar wangi yang dibeli atau diserahkan pada konsumen. Harga jual harus dapat menutup semua biaya yang dikeluarkan agar perusahaan tidak mengalami kerugian. Penentuan harga jual dalam penelitian ini dilakukan dengan metode cost plus pricing (pendekatan full costing) yaitu dengan menambahkan biaya produksi dengan persentase mark up. Menurut Mulyadi (2001) untuk mengetahui persentase mark up sesungguhnya yang telah ditetapkan perusahaan, dapat dihitung dengan cara laba yang diperoleh ditambah biaya non produksi total kemudian di bagi biaya produksi total. Besarnya persentase mark up yang sesungguhnya pada PT Pulus Wangi Nusantara dapat dilihat pada Tabel 9.

Tabel 9. Mark up pada PT Pulus Wangi Nusantara Tahun 2011 dengan perhitungan metode cost plus pricing (pendekatan full costing)

\begin{tabular}{|c|c|c|c|c|c|}
\hline Bulan & $\begin{array}{c}\text { Jumlah } \\
\text { Biaya Prod. } \\
\text { Total (Rp) }\end{array}$ & $\begin{array}{c}\text { Jumlah } \\
\text { Biaya Non } \\
\text { Prod. Total } \\
\text { (Rp) } \\
\end{array}$ & $\begin{array}{c}\text { Laba } \\
\text { Sebelum } \\
\text { Pajak 10\% } \\
(\mathbf{R p}) \\
\end{array}$ & $\begin{array}{c}\text { Mark up } \\
(\%)\end{array}$ & $\begin{array}{c}\text { Mark up } \\
\text { (Rp) }\end{array}$ \\
\hline Januari & 180.354 .994 & 4.246 .000 & $(1.000 .994)$ & 1,79 & 3.245 .006 \\
\hline Februari & 244.954 .994 & 4.348 .000 & 10.047 .006 & 5,87 & 14.395 .006 \\
\hline Maret & 249.624 .994 & 4.447 .000 & 7.728 .006 & 4,87 & 12.175 .006 \\
\hline April & 194.124.994 & 4.217 .000 & (23.141.994) & $(9,74)$ & (18.924.994) \\
\hline Mei & 229.824 .994 & 4.452 .000 & 16.423 .006 & 9,08 & 20.875 .006 \\
\hline Juni & 211.744 .944 & 4.304 .000 & 25.451 .006 & 14,05 & 29.755 .006 \\
\hline Juli & $178.274,994$ & 4.383 .000 & 11.592 .006 & 8,96 & 15.975 .006 \\
\hline Agustus & 188.034 .994 & 4.257 .000 & 7.208 .006 & 6,09 & 11.465 .006 \\
\hline September & 257.604 .994 & 4.471 .000 & 17.324 .006 & 8,46 & 21.795 .006 \\
\hline Oktober & 298.354 .994 & 4.435 .000 & 21.710 .006 & 8,76 & 26.145 .006 \\
\hline Nopember & 175.254 .994 & 4.307 .000 & 9.438 .006 & 7,84 & 13.745 .006 \\
\hline Desember & 167.504 .994 & 4.257 .000 & (15.761.994) & $(6,86)$ & (11.504.994) \\
\hline $\begin{array}{l}\text { Jumlah } \\
\text { Total }\end{array}$ & 2.575 .659 .933 & 52.124 .000 & 87.016 .072 & 59,19 & 139.140.072 \\
\hline Rata-rata & 214.638.328 & 4.343 .667 & 7.251 .339 & 4,93 & 11.595 .006 \\
\hline
\end{tabular}

Sumber: data primer diolah, 2012

Data pada Tabel 9 menunjukkan bahwa PT Pulus Wangi Nusantara selama Tahun 2011 menambahkan mark up tertinggi pada bulan Juni senilai $14,05 \%$ yang artinya pada bulan Juni perusahaan menambahkan 14,05\% dari biaya produksi total bulan Juni atau sebesar Rp29.755.006,00 yang digunakan untuk menutup biaya non produksi sebesar Rp4.304.000,00 dan menghasilkan 
laba sebelum pajak sebesar Rp25.451.006,00. Mark up terendah pada bulan April senilai $(9,7488704)$ persen dari biaya produksi total bulan April atau rugi sebesar Rp18.924.994,00 yang tidak mampu menutup biaya non produksi sebesar Rp4.217.000,00 sehingga mengalami kerugian total pada bulan April sebesar Rp23.141.994,00. Hal ini menandakan bahwa kenyataannya perusahaan tiap bulannya tidak selalu mendapatkan keuntungan dengan harga yang diterimanya.

\section{Analisis Rugi Laba PT Pulus Wangi Nusantara Periode Tahun 2011}

Laporan rugi laba dapat digunakan untuk mengetahui apakah harga jual yang ditentukan perusahaan dapat menutup seluruh biaya yang telah dikeluarkan atau sebaliknya. Laporan rugi laba merupakan suatu laporan yang sistemastis tentang penerimaan, biaya, rugi laba yang diperoleh suatu perusahaan selama periode tertentu. Laporan ini menggambarkan kemampuan perusahaan menghasilkan laba sesuai dengan tujuan perusahaan. Berdasarkan laporan rugi laba tersebut, maka dapat diketahui kemampuan perusahaan dalam menghasilkan laba atau bahkan mengalami kerugian.

Tabel 10. Laporan rugi laba PT Pulus Wangi Nusantara periode Tahun 2011.

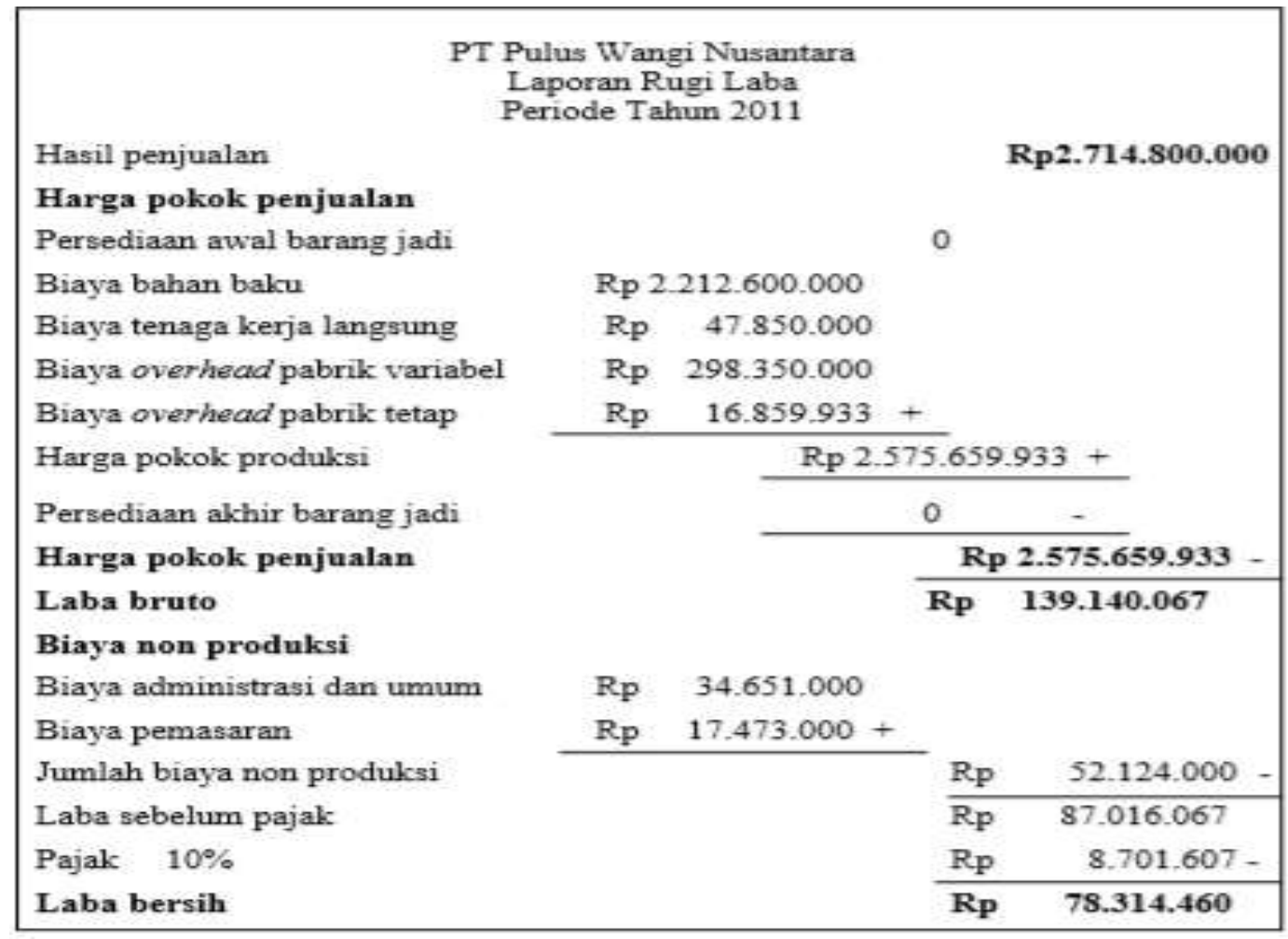

Laporan rugi laba PT Pulus Wangi Nusantara selama tahun 2011 dapat dilihat pada Tabel 10, diketahui bahwa perusahaan memperoleh penerimaan sebesar Rp2.714.800.000,00 dan keseluruhan harga pokok 
produksi sebesar Rp2.575.659.933,00, keseluruhan biaya non produksi sebesar Rp52.124.000,00 serta pajak 10 persen yaitu sebesar Rp8.701.607,00 sehingga mendapatkan laba bersih sebesar Rp78.314.460,00. Hal ini dapat diartikan bahwa harga jual yang ditentukan PT Pulus Wangi Nusantara sudah dapat menutup seluruh biaya yang dikeluarkan. Laporan rugi laba pada PT Pulus Wangi Nusantara periode tahun 2011 tersaji pada Tabel 10.

\section{KESIMPULAN DAN REKOMENDASI KEBIJAKAN}

Berdasarkan hasil penelitian mengenai perhitungan penentuan harga jual pada PT Pulus Wangi Nusantara dapat disimpulkan bahwa harga jual rata-rata minyak akar wangi yang ditetapkan PT Pulus Wangi Nusantara tahun 2011 yang dihitung melalui metode cost plus pricing menunjukkan bahwa mark up yang ditambahkan rata-rata 4,9\% dari keseluruhan biaya yang dikeluarkan dan hasil laporan rugi laba dengan pendekatan full costing menunjukkan bahwa perusahaan memperoleh laba bersih sebesar Rp78.314.460,00. PT Pulus Wangi Nusantara hendaknya mempunyai manajemen persediaan bahan baku akar wangi yang baik dan berkesinambungan. Agar bahan baku yang dibutuhkan dapat terjamin dari segi kuantitas maupun segi kualitasnya sesuai dengan kebutuhan pada waktu produksi maka perusahaan disarankan salah satunya dengan menjalin kemitraan dengan petani akar wangi. PT Pulus Wangi Nusantara hendaknya memperbaiki teknik penyulingan supaya minyak akar wangi yang dihasilkan lebih berkualitas sehingga meningkatkan harga jual minyak akar wangi itu sendiri, yang secara tidak langsung akan meningkatkan keuntungan perusahaan. PT Pulus Wangi Nusantara hendaknya memperbaiki sistem pembukuan keuangan perusahaan oleh karena itu penentapan harga jual minyak akar wangi dapat berdasarkan perhitungan biaya penuh yang terstruktur sehingga perusahaan dapat menghindari kerugian.

\section{DAFTAR PUSTAKA}

Badan Pusat Statistik.2001-2005. Perkembangan Ekspor Impor Akar Wangi di Indonesia Tahun 2001-2005 (On-line). http://www.bps.go.id Diakses pada tanggal 13 November 2011.

Badan Pusat Statistik. 2008. Statistik Ekspor Indonesia 2007. (On-line). http://www.bps.go.id. Diakses pada tanggal 27 November 2011.

Badan Pusat Statistik. 2004-2008. Perkembangan Komoditas Akar Wangi Tahun 20042008 di Kabupaten Garut (On-line). http://www.bps.go.id Diakses pada tanggal 27 November 2011. 
Departemen Pertanian. 2008. Komoditas Tanaman Akar Wangi. (On-line). http://www. ditjenbun.deptan.go.id Diakses pada tanggal 18 November 2011.

Indrawanto, Chandra. 2009. Kajian Pengembangan Industri Akar Wangi (Vetiveria zizanoides L.) Menggunakan Interpretative Structural Modelling. Jurnal Informatika Pertanian.Vol. 18. Pusat Penelitian dan Pengembangan Perkebunan, Bogor.

Jariyah, Nur Ainun dan Agung B. Supangat. 2007. Dilema Penanaman Akar Wangi (Vetiveria zizanoides L. Nash) di Kabupaten Garut. Jurnal Info Hutan. Vol. 5. Balai Penelitian Kehutanan Solo, Solo.

Mulyadi. 2005. Akuntansi Biaya. UPP AMK YKPN, Yogyakarta.

Sugiri, Slamet.1999. Akuntansi Manajemen. UPP AMK YKPN, Yogyakarta. 